\title{
Control of Sensory Activation of Granule Cells in the Fascia Dentata by Extrinsic Afferents: Septal and Entorhinal Inputs
}

\author{
Thomas C. Foster, Robert E. Hampson, Mark O. West, and Sam A. Deadwyler \\ Department of Physiology and Pharmacology, Bowman Gray School of Medicine of Wake Forest University, Winston- \\ Salem, North Carolina 27103
}

\begin{abstract}
Three groups of rats were trained to perform a differential discrimination task in a 2-tone operant conditioning paradigm. One group received electrolytic lesions of the medial septal nuclei, another received electrolytic or knife cut lesions of the entorhinal cortex. These groups were compared with a normal control group. Recordings of granule cells in the fascia dentata were obtained in all animals during criterion performance of the behavioral task. Both lesions produced disruption of behavioral discrimination in the form of increased error and intertrial responding. Granule cell discharges to the tone stimuli were disrupted by each type of lesion. Septal lesions reduced the differential discharge tendency to $\mathrm{CS}^{+}$and $\mathrm{CS}^{-}$and changed granule cell firing on all trials to statistically resemble firing on $\mathrm{CS}^{-}$trials in normal animals. Extensive lesions in the entorhinal cortex or knife cuts that severed the perforant path caused near elimination of the tone-evoked discharges to both the $\mathrm{CS}^{+}$and $\mathrm{CS}^{-}$tones. Septal and entorhinal lesions caused marked changes in the sequential dependence of the granule cell discharge compared with intact animals. Results are discussed in terms of the control of the granule cell discharge by the remaining afferent pathways in each type of lesion condition.
\end{abstract}

The major extrinsic synaptic connections to the granule cells of the dentate gyrus in the rat originate in or traverse through the brain stem and septal area (Lynch et al., 1977; Swanson et al., 1987) or entorhinal cortex (EC) (Hjorth-Simonsen and Jeune, 1972). The connections from the $\mathrm{EC}$ terminate in the outer twothirds of the molecular layer of the dentate gyrus via en passage contacts from axons of the perforant path that originate in the superficial layers of the EC (Steward, 1976). The EC in turn receives substantial afferent input from neocortical and subcortical regions (Van Hoesen et al., 1972; Beckstead, 1978). The perforant path provides the initial synaptic connections between the cortex and hippocampus, providing powerful excitatory control over the dentate granule cells (Dudek et al., 1976; Fricke and Prince, 1984). Neurobehavioral studies suggest that the perforant path is involved in the transmission of sensory in-

Received Nov. 14, 1987; revised Feb. 12, 1988; accepted Feb. 29, 1988.

This work was supported by NIH Grants DA03502, DA04441, and DA02048 to S.A.D. We wish to thank Sonia Stitcher for her assistance in preparing this manuscript and Greg Marlow for assistance in preparing the figures.

Correspondence should be addressed to Sam A. Deadwyler, Ph.D., Department of Physiology and Pharmacology, Bowman Gray School of Medicine, 300 S. Hawthorne Road, Winston-Salem, NC 27103.

Copyright (C) 1988 Society for Neuroscience $0270-6474 / 88 / 103869-10 \$ 02.00 / 0$ formation to the dentate gyrus (Wilson and Steward, 1978; Deadwyler et al., 1981; Deadwyler, 1985).

Projections from the medial septal nuclei and brain stem areas are located throughout the dentate gyrus, with terminations in the infra- and supragranular zones (Raisman, 1966; Mosko et al., 1973; Segal and Landis, 1974; Rose et al., 1976; Lynch et al., 1977). Destruction of the septal region results in a pronounced loss of the theta rhythm and accompanying rhythmic granule cell discharges (Bland et al., 1983). Studies in both anesthetized and behaving animals have suggested that the medial septal input exerts inhibitory influences on the sensory evoked discharges of dentate granule cells (Hirsh, 1973; Miller and Groves, 1977). Paired-pulse electrical stimulation of the septum increases the amplitude of the cortically (perforant path) elicited population spike recorded in the granule cell layer, suggesting a facilitatory interaction between the septal and entorhinal afferent pathways on the dentate granule cells (Alvarez-Leefmans and Gardner-Medwin, 1975; Fantie and Goddard, 1983; McNaughton and Miller, 1984; Bilkey and Goddard, 1987). These findings suggest that the subcortical (septal and brain stem) and cortical afferents to the hippocampus exert powerful influences over the firing tendencies of dentate granule cells. The following study was designed to investigate the role of these respective afferents in the control of sensory evoked activity of dentate granule cells in behaving rats.

\section{Materials and Methods}

Lesions. The lesions were planned to strategically deafferent the hippocampus from its 2 major sources of fiber input, rostrally via damage to the septum and fornix and caudally via destruction or isolation of the EC. For convenience, we will refer to the animals receiving the former type of lesion as the MS (medial septum) group and the latter as the EC group. Male Sprague-Dawley rats $(n=16)$ (Harlan Sprague Dawley, Indianapolis, IN) $100-150 \mathrm{~d}$ of age were anesthetized with sodium pentobarbital $(35 \mathrm{mg} / \mathrm{kg})$, supplemented with chloral hydrate (15 mg). Animals in the MS group received bilateral electrolytic destruction of the medial septal nucleus (coordinates: $0.5 \mathrm{~mm}$ anterior to bregma, $0.5 \mathrm{~mm}$ lateral, and $5.5 \mathrm{~mm}$ ventral; $1.5 \mathrm{~mA}$ anodal current for $10 \mathrm{sec}, n-5$ ). Two animals in the EC group received electrolytic destruction (coordinates: $3.5 \mathrm{~mm}$ lateral to the midline, $1-5 \mathrm{~mm}$ anterior to the transverse sinus, $0.5 \mathrm{~mm}$ medial inserted at a $10^{\circ}$ angle away from the midline; $2.0 \mathrm{~mA}$ for $30 \mathrm{sec}$ at 2,4 , and $6 \mathrm{~mm}$ ventral to the dura, $n=2$ ) of the EC. Bilateral isolation of the EC was also performed via stereotaxic knife cuts (Gold et al., 1973) in 4 other animals in the EC group (coordinates: $2.5 \mathrm{~mm}$ lateral to the midline, $1.5 \mathrm{~mm}$ anterior to the transverse sinus, $2.0 \mathrm{~mm}$ ventral to the dura, the knife was extended out of the carriage needle $2.5 \mathrm{~mm}$ lateral, and lowered 5.0 $\mathrm{mm}$ ventral).

Surgical procedure for recording. A removable microdrive recording system (Deadwyler et al., 1979a) was surgically placed to allow the recording electrode to be positioned in the CA1 and dentate gyrus subregions of the hippocampus (coordinates: $3.8-4.0 \mathrm{~mm}$ posterior and 2.0 
$2.1 \mathrm{~mm}$ lateral to bregma). Bipolar stimulating electrodes $(100 \mu \mathrm{m}$ twisted stainless steel wires) were permanently implanted in selected animals in one or both of the following pathways: ipsilateral perforant path (coordinates: $3.5 \mathrm{~mm}$ lateral to the midline, $1.5 \mathrm{~mm}$ anterior to the transverse sinus, $0.5 \mathrm{~mm}$ medial and inserted at an angle $10^{\circ}$ away from the midline) or the contralateral hippocampal commissure (HC; coordinates: $1.3-1.6 \mathrm{~mm}$ posterior, $1.1-1.3 \mathrm{~mm}$ lateral to bregma). An uninsulated $100 \mu \mathrm{m}$ stainless steel wire was implanted in the frontal cortex and used as a reference electrode during recording. Hippocampal field potentials evoked from both stimulation sites were monitored during surgical preparation to insure correct placement of recording and stimulating electrodes.

Stimulating and reference electrodes were attached to an electrical connector and permanently affixed to the skull with acrylic dental cement and jeweler's screws. Bicillin (i.e., 35,000 U) was administered intramuscularly, and Neosporin antibacterial ointment was applied around the scalp wound. Following surgery and prior to beginning the experimental procedures, all animals were fed food and water ad libitum and allowed to recover their preoperative weights.

Tone discrimination training. The apparatus consisted of a rectangular Plexiglas box $(20 \times 23 \times 53 \mathrm{~cm})$ housed in a larger sound-attenuated and electrically shielded chamber (Industrial Acoustics Co.). An aluminum block containing a light source and photocell separatcd by a 1 inch slot was mounted in the box on one wall. A nose poke by the animal breaking the light beam activated a solenoid, which delivered a drop of water into a trough located on the opposite wall of the chamber. Tone stimuli were delivered via a speaker mounted on an adjacent wall. A recording cable was suspended from the top of the box via a slip ring commutator, which allowed the animal freedom of movement during recording sessions.

Following recovery from lesions and surgery (7-15 d), animals were water deprived to $85-90 \%$ of preoperative weight and trained to criterion on a 2-tone (tone $1: 3.0 \mathrm{kHz}, 55 \mathrm{~dB}$; tone $2: 1.0 \mathrm{kHz}, 64 \mathrm{~dB}$ ) successive auditory discrimination task. Both tones were presented randomly, one on each trial, with a mean intertrial interval of $60 \mathrm{sec}$ and range of 30-90 sec. A nose poke within $5.0 \mathrm{sec}$ halted the tone and produced a water reward if pcrformed in the presence of the $\mathrm{CS}^{+}$(rewarded tone). A nose poke during the $\mathrm{CS}^{-}$(nonrewarded tone) immediately terminated the trial without reward. Tones were randomly assigned as $\mathrm{CS}^{+}$and $\mathrm{CS}^{-}$among the animals in each group. Criterion performance consisted of $\geq 90 \%$ responding to the $\mathrm{CS}^{+}$and $\leq 30 \%$ responding to the $\mathrm{CS}^{-}$and was achieved in all animals within 20 daily training sessions.

Chronic unit recording. Before each recording session, an etched, epoxyinsulated, tungsten microelectrode (1-3 $\mu \mathrm{m}$ tip size, $2-7 \mathrm{M} \Omega$ impedance at $100 \mathrm{~Hz}$ ) was lowered into the granule cell layer of the dentate gyrus via the microdrive assembly. Neural activity was led through field-effect transistors in the head stage of the recording cable, amplified, and lowor high-pass-filtered $(500 \mathrm{~Hz}-10 \mathrm{kHz})$ for respective EEG and spike analyses. The microelectrode was localized in the dentate granule cell layer by monitoring field potentials elicited by electrical stimulation of the perforant path or commissural system (Bliss \& Lomo, 1973; Deadwyler et al., 1975; Fox and Ranck, 1979; Deadwyler et al., 1981). Since the duration of the granule cell extracellular action potential is considered to be similar to that recorded from theta cells (Fox and Ranck, 1981), this criterion could not be used to identify granule cells (Buzsaki et al., 1983; Foster et al., 1987). Consequently, extracellular action potentials were isolated at greater than 3:1 signal-to-noise ratio and classified as granule cells according to 4 other criteria: (1) localization of the microelectrode in the granule cell layer, (2) an action potential latency $\leq 5.0 \mathrm{msec}$ following single pulse stimulation of the perforant path (Lømo, 1971; Buzsaki et al., 1983; Foster et al., 1987), (3) spontaneous firing consisting of only single action potentials and never complex spikes (Bland et al., 1980; Foster et al., 1987), and (4) production of only a single action potential cven at high perforant path stimulation intensities (Buzsaki et al., 1983; Fricke and Prince, 1984; Foster et al., 1987). Although absolute identification of granule cells versus other cell types in the granule cell layer is not possible with extracellular recording techniques, criterion 4 is the most critical for distinguishing granule cells from theta cells (Buzsaki et al., 1983; Foster et al., 1987). Cells not meeting the 4 criteria were not used in this study.

Data analyses. Single trial records of identified granule cell activity (spikes) similar to those previously published by this laboratory (Campbell et al., 1986) were collected during criterion peformance of the 2-tone discrimination task over a $30 \mathrm{~d}$ training period. Spike activity was sorted into 160 consecutive $10 \mathrm{msec}$ intervals (bins), summed, and normalized into perievent histograms consisting of $50 \mathrm{CS}^{+}$and $\mathrm{CS}^{-}$trials for each session. At least 3 recording sessions for each animal were obtained for each group (approximately 20 sessions), accounting for a total of 2000 trials. Means and SDs of granule cell firing rate (spikes/sec) were computed from normalized ( $10 \mathrm{msec}$ interval) histograms from $200 \mathrm{msec}$ before to $400 \mathrm{msec}$ after tone onset. A standard $(z)$ score was derived by subtracting the mean pretone rate from the mean rate at different posttone time intervals and dividing by the SD of the pretone firing ratc (Christian and Deadwyler, 1986; Foster et al., 1987). One- and twoway ANOVAs were used to analyze standard scores as a function of group differences and trial type $\left(\mathrm{CS}^{+}\right.$or $\left.\mathrm{CS}^{-}\right)$.

The effects of septal and entorhinal lesions on granule cell discharges were also investigated in relation to the influence of prior trial sequences (Deadwyler et al., 1985; Foster et al., 1987). Analyses of sequential dependencies were conducted by sorting trial-specific granule cell discharges into different $\mathrm{CS}^{+}$and $\mathrm{CS}^{-}$sequence categories defined by the 5 trials that preceded the "current" trial on which the tone-evoked discharge occurred. Since each of these $32\left(2^{5}\right)$ possible trial sequences could be associated with a $\mathrm{CS}^{+}$or $\mathrm{CS}^{-}$on the current trial, there were 64 possible categories of sequence-related granule cell firing tendencies (Foster et al., 1987).

Histology. Following the final recording session, animals wcre sacrificed by an overdose of sodium pentobarbital and perfused with physiological saline followed by $10 \%$ formalin, and the brains removed and placed in $10 \%$ formalin for sectioning. Sections were cut in the coronal and horizontal planes, mounted on slides and stained with cresyl violet. Lesions were examined for extent of neuronal damage to targeted and adjacent structures. Recording and stimulating electrode tracks were verified in coronal sections.

\section{Results}

\section{Histology}

Bilateral electrolytic lesions directed at the medial septal area resulted in destruction of the medial septum in all animals included in the MS group, with concomitant damage in some animals extending to include the lateral septum, fornix, and fimbria (Fig. 1A). It should be noted, however, that such lesions, even if restricted to the medial septal nucleus, would involve damage to other hippocampal afferent fiber systems and their respective transmitters, including the projections from locus coeruleus, Raphe, and diagonal band pathways (Swanson et al., 1987). Therefore, reference to the effects of medial septal lesions in this study will include damage to fibers of passage in addition to the area targeted by the lesion. There were, however, no significant differences in physiological or behavioral measures obtained between animals in the MS group which were correlated with the extent of damage to adjacent structures. Bilateral electrolytic lesions of the EC in 2 animals resulted in destruction of the medial and lateral divisions of the EC and extended to include portions of the parasubiculum, presubiculum, and surrounding neocortex (Fig. $1 B$ ). Knife cut lesions severed the angular bundle bilaterally in 4 other animals with minimal damage extending to include the para- and presubiculum and overlying neocortex (Fig. 1C). Again, there were no statistical differences in behavioral or physiological measures between animals in the EC group with electrolytic lesions or knife cut isolation of the EC.

\section{Effects of septal and entorhinal lesions on tone discrimination behavior}

One- or two-way ANOVAs performed across sessions and animals revealed a significant $\left(F_{2,53}=3.78, p<0.05\right)$ effect of the lesion on intertrial responding by the EC and MS groups. This is illustrated in Figure 2, with the EC group showing slightly, but not significantly, higher mean intertrial responses than the 


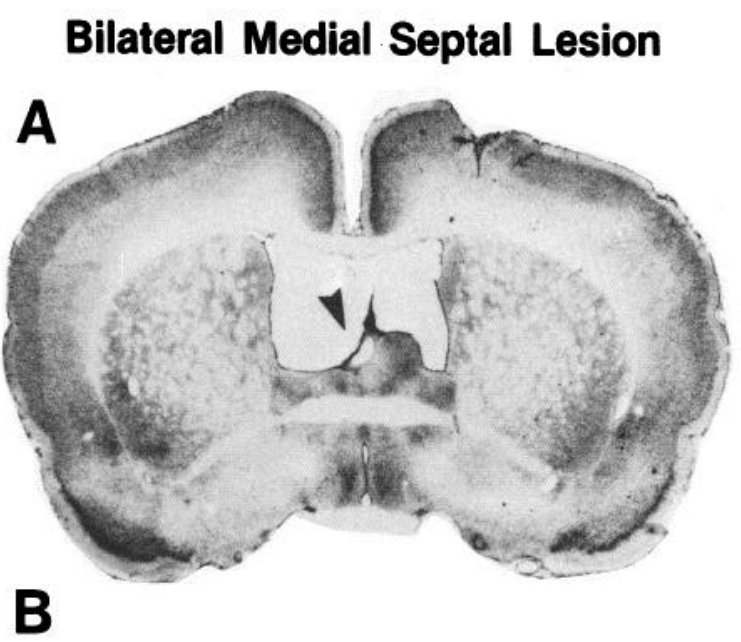

\section{Bilateral Entorhinal Cortex Lesion}

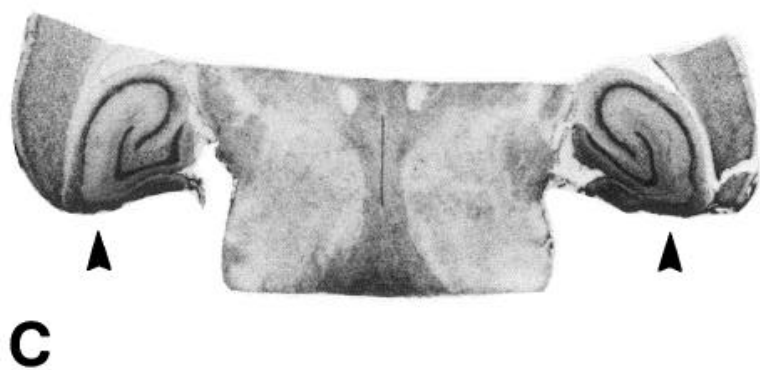

\section{Bilateral Entorhinal Cortex Isolation}

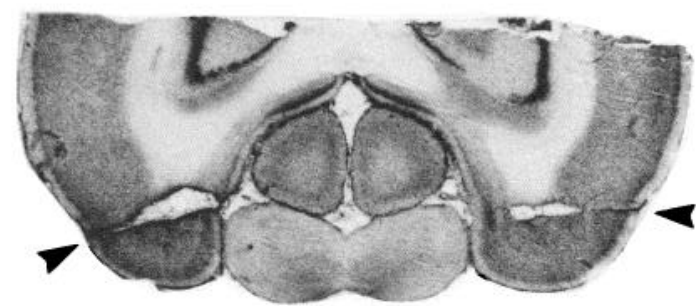

Figure 1. Photomicrographs depicting the 3 types of lesions. $A, \mathrm{Co}-$ ronal section showing largest electrolytic septal lesion. $B$, Horizontal section showing results of electrolytic lesion of entorhinal cortex (EC). $C$, Horizontal section showing knife cut damage producing isolation of the EC with stereotaxic knife cut severance of angular bundle. Arrows denote sites of lesions.

MS group. Mean behavioral response latencies on $\mathrm{CS}^{+}$and $\mathrm{CS}^{-}$ trials were compared for each group and there were no significant differences among the 3 groups (control, $1.43 \pm 0.35$; EC, 1.45 $\pm 0.25 ; \mathrm{MS}, 1.41 \pm 0.25 \mathrm{sec})$.

Tone discrimination behavior in terms of selective responding to the $\mathrm{CS}^{+}$or $\mathrm{CS}^{-}$was analyzed across sessions and animals for each group. The mean percent responses on $\mathrm{CS}^{+}$and $\mathrm{CS}^{-}$trials are shown in Table 1. A 2-way ANOVA revealed a highly significant $(p<0.001)$ main effect of trial type $\left(\mathrm{CS}^{+}\right.$or $\left.\mathrm{CS}^{-}\right)$, indicating effective tone discrimination performance in all groups. Individual comparisons (contrasts) confirmed that all 3 groups in Table 1 exhibited significantly different responding on $\mathrm{CS}^{+}$ versus $\mathrm{CS}^{-}$trials (controls, $F_{1,120}=929.56$; $\mathrm{EC}, F_{1,120}=817.14$; MS, $\left.F_{1,120}=816.25 ; p<0.01\right)$. Two-way ANOVAs compared all 3 groups separately with each other and showed a significant main effect of the lesion $\left(F_{2,63}=8.158, p<0.001\right)$ on increased

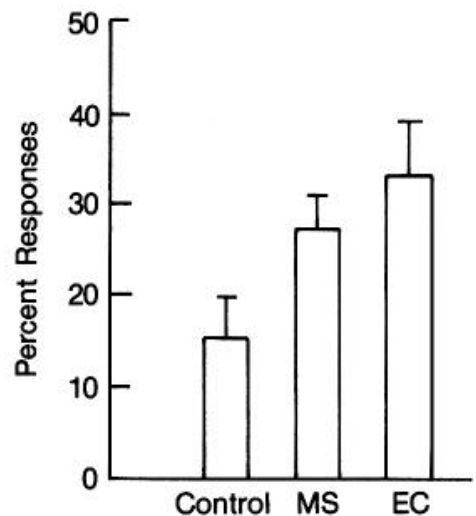

Figure 2. Mean percent intertrial responses for each of the 3 groups; MS, EC, and control, indicating percentage of responses that occurred other than during $\mathrm{CS}^{+}$and $\mathrm{CS}^{-}$stimulus presentations (shown in Table 1). Bars represent \pm SEM.

responding on $\mathrm{CS}^{-}$trials by the $\mathrm{MS}\left(F_{2,63}=4.896, p<0.025\right)$ and EC groups $\left(F_{2,63}=7.333, p<0.005\right)$ compared with the control group. The mean number of responses on $\mathrm{CS}^{+}$trials was not significantly different among any of the groups (Table 1).

\section{Effects of EC and MS lesions on granule cell discharge}

Figure 3 shows normalized perievent time histograms (PTHs) of tone-evoked granule cell activity for all 3 groups on $\mathrm{CS}^{+}$and $\mathrm{CS}^{-}$trials. Spontaneous granule cell activity measured during the $200 \mathrm{msec}$ prior to tone onset was not significantly influenced by the type of lesion or trial. The mean $( \pm$ SEM) pretone granule cell firing rate for the control group was $18.6 \pm 2.0$ spikes $/ \mathrm{sec}$; MS, $15.75 \pm 1.72$ spikes/sec; and EC, $14.2 \pm 1.64$ spikes/sec. There were marked differences in the tone-evoked discharge rates between the 3 groups. The mean tone-evoked discharge rate for the control group was $28.83 \pm 3.71$ for the $\mathrm{CS}^{+}$and $24.91 \pm 3.93$ for the $\mathrm{CS}^{-}$; the rate for the MS group on $\mathrm{CS}^{+}$ trials was $25.10 \pm 3.08$ and $21.97 \pm 2.31$ on $\mathrm{CS}^{-}$trials; for the EC group, the tone-evoked discharge rate did not differ significantly from the pretone rate, consisting of $18.12 \pm 1.77$ for the $\mathrm{CS}^{+}$and $14.55 \pm 1.41$ for the $\mathrm{CS}^{-}$. The mean latency-to-peak (i.e., maximum) firing on $\mathrm{CS}^{+}$trials for each group was as follows: control, $90 \mathrm{msec}$; MS, $100 \mathrm{msec}$; and EC, $120 \mathrm{msec}$; on $\mathrm{CS}^{-}$trials: controls, $100 \mathrm{msec}$ and MS and EC, $80 \mathrm{msec}$ (Fig. 3).

Previous reports have demonstrated that in normal animals the discharge characteristics of granule cells to the $\mathrm{CS}^{+}$and $\mathrm{CS}^{-}$ are markedly different (Foster et al., 1987). A 2-way ANOVA revealed significant main effects of both lesion and trial type on standard $(z)$ scores of granule cell discharge measured over the entire $400 \mathrm{msec}$ posttone analysis period (lesion: $F_{2,120}=7.96$, $p<0.01$; trial type: $F_{1,120}=7.38, p<0.01$ ). However, individual contrasts showed that only control group tone-evoked dis-

Table 1. Behavioral response measures (means \pm SEM)

\begin{tabular}{llr} 
& \multicolumn{2}{l}{ \% Responses } \\
\cline { 2 - 3 } Group & $\mathrm{CS}^{+}$trials & \multicolumn{1}{c}{$\mathrm{CS}^{-}$trials } \\
\hline Control $(n=23)$ & $97.5 \pm 1.3$ & $3.9 \pm 1.0$ \\
MS lesion $(n=21)$ & $98.0 \pm 0.8$ & $10.3 \pm 1.5$ \\
EC lesion $(n=22)$ & $98.7 \pm 0.4$ & $10.9 \pm 1.7$ \\
\hline
\end{tabular}


Figure 3. Discharge pattern of identified granule cells for each of the 3 groups (MS, EC, and control) for $\mathrm{CS}^{+}$ and $\mathrm{CS}^{-}$trials. Each perievent histogram (PSTH) shows the mean spike counts normalized for trial number averaged over approximately 20 different cells in each group. Calibration: 0.2 spike counts/10 msec (bin), 200 spikes.
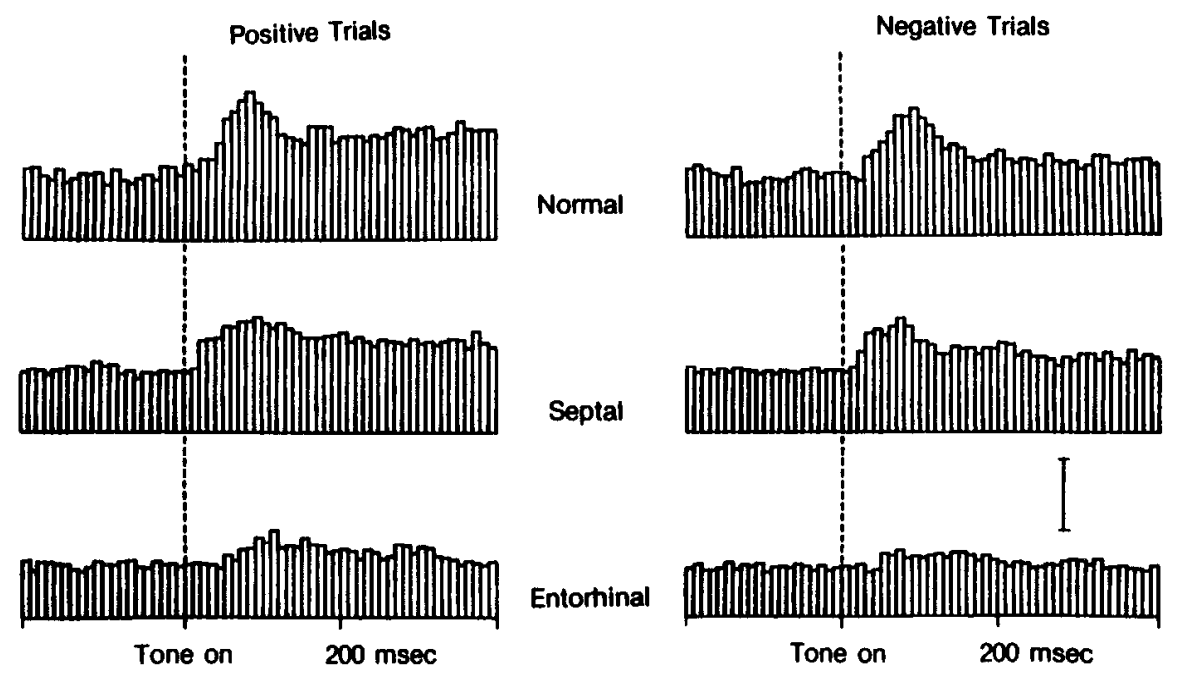

charges were significantly different on $\mathrm{CS}^{+}$versus $\mathrm{CS}^{-}$trials $\left(F_{1,120}=4.31, p<0.05\right)$. Control group discharges were significantly increased over the EC group but not the MS group on both $\mathrm{CS}^{+}\left(F_{2,120}=4.76, p<0.05\right)$ and $\mathrm{CS}^{-}$trials $\left(F_{2,120}-3.35\right.$, $p<0.05)$. This difference resulted from the absence of a significant increase in mean granule cell discharge to the tone stimuli in the EC group (Fig. 3).

The loss of responsiveness of granule cells to the $\mathrm{CS}^{+}$and $\mathrm{CS}^{-}$ in the EC group (Fig. 3) required confirmation that the deficit in this group resulted from severing the connection between the EC and dentate gyrus and not from inadvertent damage to the hippocampus. One animal was therefore tested before and after the knife cut procedure (the same animal shown in Fig. 1C). Figure 4 shows normalized PSTHs of identified granule cells

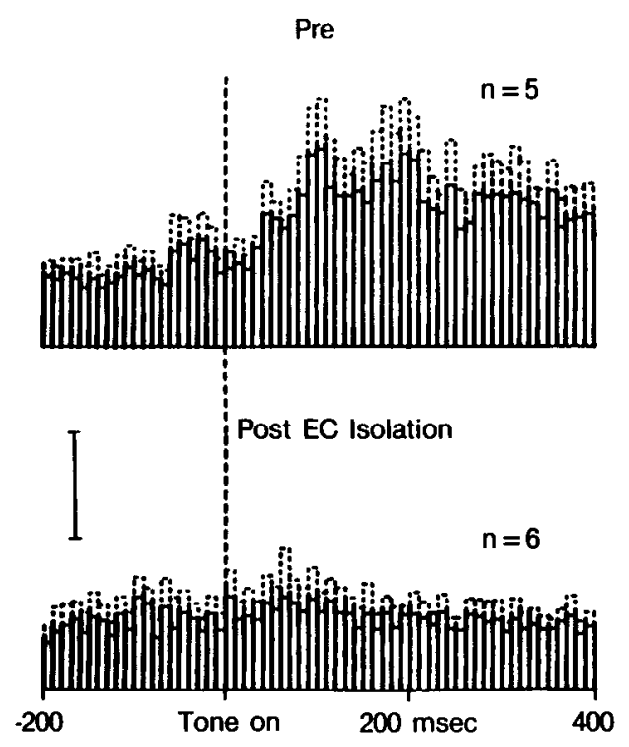

Figure 4. Effect of EC lesion on tone-evoked granule cell discharge. Mean perievent histograms (solid line) and SEM (dashed line) of toneevoked granule cell discharges on $\mathrm{CS}^{+}$trials. Top, Normalized PTH averaged over 5 cells (sessions) before production of lesion. Bottom, PTHs from 6 cells recorded from the same animal after knife cut isolation of the EC (shown in Fig. 1C). Fach histogram reflects normalized spike counts recorded from an identified granule cell in a session consisting of 200 trials. Calibration: 0.2 spikes $/ 10 \mathrm{msec}, 10$ spikes. recorded from different daily sessions before and after the knife cut lesion was performed. There was a complete elimination of granule cell tone-evoked discharges (as indicated by $z$-score) to both the $\mathrm{CS}^{+}$and $\mathrm{CS}^{-}\left(F_{1,9}=5.91, p<0.05\right)$ after the lcsion. This was similar to the deficit obtained across all animals in the bilateral FC. group (Fig. 3).

\section{Effects of lesions on the topography of tone-evoked granule cell discharge}

The temporal firing patterns of granule cells evoked by the tone stimuli have distinct topographic characteristics in normal animals that are manifested as variances in the elevated rates of discharge at different times following tone onset (Deadwyler et al., 1979a, b; Foster et al., 1987). Similar patterns to those shown previously were obtained in the control group in this study (Fig. 3 ). The firing pattern to the $\mathrm{CS}^{+}$consisted of a $20-40 \mathrm{msec}$ latency (delay) between tone onset and posttone granule cell firing, which increased rapidly over the next $50 \mathrm{msec}$ to a peak discharge at $80-100 \mathrm{msec}$ after tone onset. Following this peak, there was a decline and stabilization of firing in the 100-200 msec interval to a rate midway between the background (pretone) and peak firing rate (Fig. 3). The firing rate in the $200-$ $400 \mathrm{msec}$ interval remained elevated until response execution (Deadwyler et al., 1979a, b; West et al., 1982) and was significantly elevated $(p<0.025)$ relative to firing on $\mathrm{CS}^{-}$trials within the same posttone interval. This latter period $(200-400 \mathrm{msec})$ of increased granule cell firing we have shown coincides with initiation of the behavioral response to the $\mathrm{CS}^{+}$(West et al., 1982; Christian and Deadwyler, 1986). The discharge profile for $\mathrm{CS}^{-}$trials in the control group was very similar to the $\mathrm{CS}^{+}$ pattern during the $0-100 \mathrm{msec}$ interval after tone onset and did differ significantly. After $100 \mathrm{msec}$ in the posttone interval, firing to the $\mathrm{CS}^{-}$gradually declined to the pretone rate and did not differ significantly from the pretone rate in the $200-400 \mathrm{msec}$ posttone interval.

The relationship of these differences in topography of granule cell discharge among the 3 groups in terms of significant differences in $z$-scores calculated for the various posttone intervals is shown in Table 2. In the MS group, granule cell firing rate on $\mathrm{CS}^{+}$trials was significantly $(p<0.05)$ elevated in the 100 $200 \mathrm{msec}$ period compared with pretone rate and the rate in the same interval on $\mathrm{CS}^{-}$trials. There were no differences in 


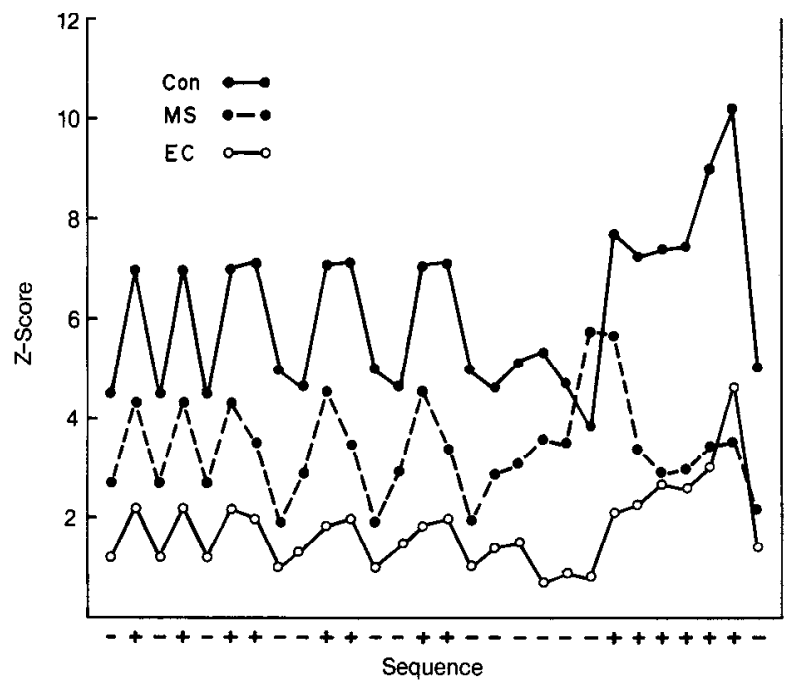

Figure 5. Sequential dependencies of granule cell discharge ( $z$-scores) patterns for each group (MS, EC, and control) reconstructed from individual trial data sorted as a function of the preceding trial sequence. The $z$-score is calculated for the trial indicated in the sequence (i.e., the "current" trial). The reconstruction of the series depicts granule cell discharges for 3 basic categories of trial sequence: single alternation, double alternation, and runs of $\mathrm{CS}^{+}$and $\mathrm{CS}^{-}$trials, as well as transitions between each sequence. Symbols: MS, solid circles and dashed line; EC, open circles and solid lines; control, solid circles and lines.

granule cell firing rates in the MS group on $\mathrm{CS}^{+}$and $\mathrm{CS}^{-}$trials during the $200-400 \mathrm{msec}$ posttone interval. The granule cell firing rate to both the $\mathrm{CS}^{-}$and $\mathrm{CS}^{+}$for this group was also not significantly different from the rate on CS - trials for the control group (Table 2 ). The statistically significant elevated granule cell discharge to the $\mathrm{CS}^{+}$during the $200-400 \mathrm{msec}$ interval seen in the control group was therefore absent (Table 2) in the otherwise similar $\mathrm{CS}^{+}$evoked discharge in the MS group (Fig. 3).

By far the most striking effect observed in these studies was the absence of significant tone-evoked granule cell discharge in the EC group. The only indication of a change in firing in the EC group was a slight increase in granule cell firing rate in 100 $200 \mathrm{msec}$ posttone interval (Fig. 3), but this increase was not significant. The complete absence of posttone granule cell firing in the EC group rendered this group significantly different from both the control and MS groups in most intervals with respect

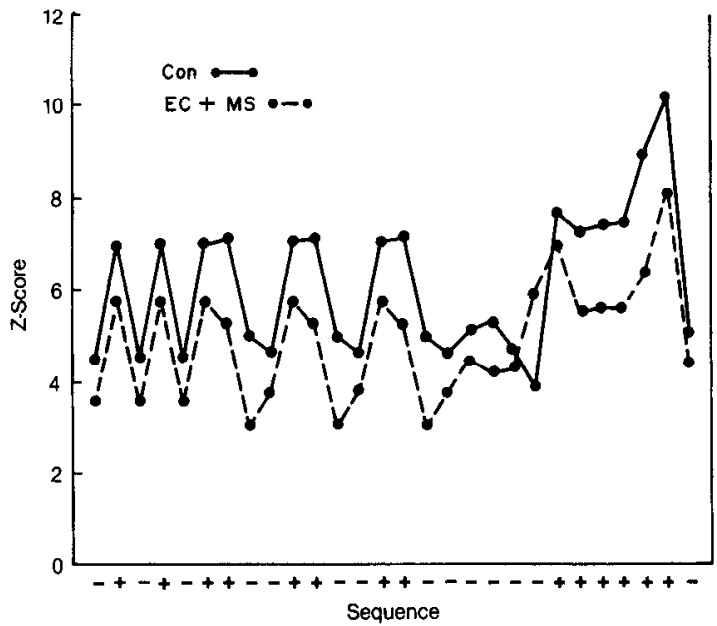

Figure 6. Sequential granule cell discharge pattern for control and combined MS and EC $z$-scores over the same trial sequence. The pattern of fluctuation in granule cell $z$-scores for controls (solid line) was obtained by summation of mean MS and EC $z$-scores (dashed line) for each trial position in the series shown in Figure 5.

to $\mathrm{CS}^{+}$(control vs. EC, $p<0.001$; MS vs. EC, $p<0.001$ ) and $\mathrm{CS}^{-}$trials (control vs. EC, $p<0.001$; MS vs. EC, $p<0.01$ ). These comparisons are also shown in Table 2.

\section{Effects of lesions on sequentially dependent granule cell firing}

A detailed representation of trial-to-trial sequential changes in granule cell discharge ( $z$-score) for all 3 groups is illustrated in Figure 5 for a sequence constructed from the 64 possible sequence categories (see Materials and Methods). During single alternation sequences, oscillations in the granule cell discharge pattern were controlled by the trial type $\left(\mathrm{CS}^{+}\right.$or $\left.\mathrm{CS}^{-}\right)$for each of the 3 groups, the only differences being the magnitudes of the discharges ( $z$-scores). As the sequence changed to double alternation, the pattern of discharge within each group changed. In the control group, granule cell discharges continued to track the current trial type $\left(\mathrm{CS}^{+}\right.$or $\left.\mathrm{CS}^{-}\right)$as described in previous reports (Foster et al., 1987). In the MS group, fluctuations in granule cell discharge "drifted" out of phase with the current trial, showing delayed shifts in firing maximums and minimums relative to the control group (e.g., to the second trial in the double alternating sequence, Fig. 5). The EC group also showed

Table 2. Significance of topographic changes in granule cell discharge pattern within and between groups over 4 temporal intervals following tone onset

\begin{tabular}{|c|c|c|c|c|c|c|c|c|}
\hline \multirow[b]{3}{*}{ Trial type } & \multicolumn{8}{|c|}{ Posttone interval ${ }^{a}$} \\
\hline & \multicolumn{2}{|l|}{$0-50 \mathrm{msec}$} & \multicolumn{2}{|c|}{$50-100 \mathrm{msec}$} & \multicolumn{2}{|c|}{$100-200 \mathrm{msec}$} & \multicolumn{2}{|c|}{$200-400 \mathrm{msec}$} \\
\hline & $\overline{\mathrm{CS}^{+}}$ & $\mathrm{CS}^{-}$ & $\overline{\mathrm{CS}^{+}}$ & $\mathrm{CS}^{-}$ & $\mathrm{CS}^{+}$ & $\mathrm{CS}^{-}$ & $\mathrm{CS}^{+}$ & $\mathrm{CS}^{-}$ \\
\hline \multicolumn{9}{|l|}{ Between groups } \\
\hline Control vs. MS & & & $p \leq 0.01$ & $p \leq 0.05$ & & & $p \leq 0.05$ & \\
\hline Control vs. EC & $p \leq 0.01$ & $p \leq 0.01$ & $p \leq 0.01$ & $p \leq 0.01$ & $p \leq 0.01$ & $p \leq 0.01$ & $p \leq 0.01$ & $p \leq 0.05$ \\
\hline MS vs. EC & $p \leq 0.01$ & $p \leq 0.01$ & $p \leq 0.05$ & $p \leq 0.05$ & $p \leq 0.05$ & $p \leq 0.05$ & & $p \leq 0.05$ \\
\hline \multicolumn{9}{|l|}{ Within group } \\
\hline Control & & & & & $p \leq 0.05$ & & $p \leq 0.01$ & \\
\hline MS & & & & & $p \leq 0.05$ & & & \\
\hline EC & & & & & & & & \\
\hline
\end{tabular}




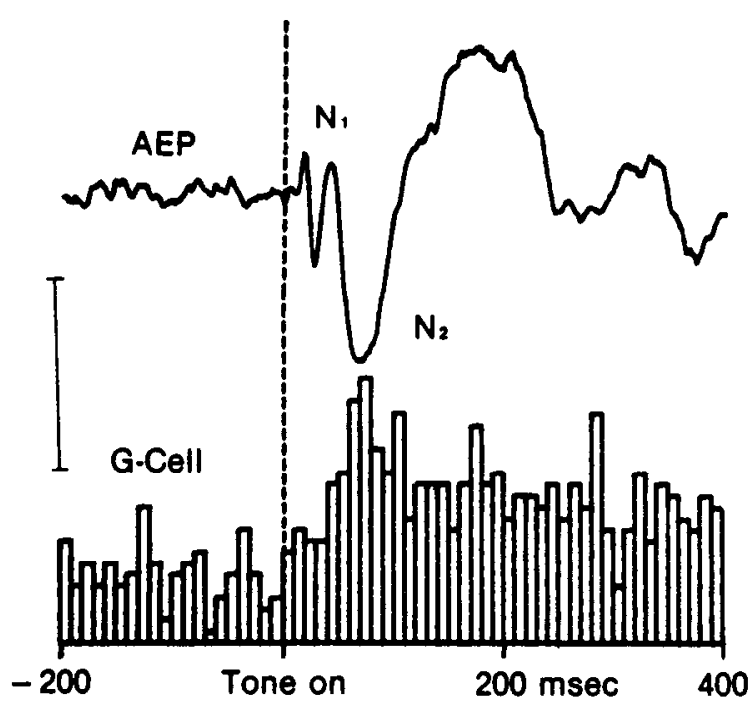

Figure 7. Dual-channel simultaneous recording of averaged evoked potential $(A E P)$ to the tone stimulus recorded from the dentate gyrus outer molecular layer (point of maximum negativity of perforant path field potential) and PTH of spikes from a granule cell $(G$-Cell $)$ recorded concurrently during performance of the auditory discrimination task. $\mathrm{N} 1$ and $\mathrm{N} 2$ denote identified synaptic components of the evoked potential reflecting perforant path and septal inputs, respectively. Both the evoked potential and PTH were constructed from $50 \mathrm{CS}^{+}$trials. Calibration: $300 \mu \mathrm{V}$; PTH, 0.2 spike counts $/ 10 \mathrm{msec}, 10$ spikes.

a delayed shift from current trial-specific firing, but the shift was 2 trials removed from the control group and 1 trial removed from the MS group. Differences among the 3 groups were also apparent during runs of $\mathrm{CS}^{-}$trials where granule cell discharges of the MS group increased with each additional trial in the run, but control and EC groups decreased or remained at minimal levels. When the sequence changed abruptly to a run of $\mathrm{CS}^{+}$ trials, firing in the EC and control groups was significantly ( $p<$ $0.05)$ increased, while in the MS group tone-evoked firing was significantly $(p<0.05)$ decreased across the run (Fig. 5).

The effects of the 4 different sequences shown in Figure 5, including runs of $\mathrm{CS}^{+}$and $\mathrm{CS}^{-}$trials, were analyzed by 2 -way ANOVA for influences on tone-evoked granule cell discharges ( $z$-scores). EC lesioned animals showed no statistically significant influence of sequence and almost exclusive control by the current trial during all sequences except runs of $\mathrm{CS}^{+}$trials $(p<$ 0.05 ). Granule cell discharges of animals in the MS group were influenced more by the sequence of preceding trials during runs of $\mathrm{CS}^{+}$and CS trials regardless of current trial type, reflecting a significant $(p<0.01)$ decrease in current trial influence (versus single and double alternation) and increased control by the preceding sequence in comparison with similar measures in the control and EC groups. These effects undoubtedly contributed to the lack of distinction between $\mathrm{CS}^{+}$and $\mathrm{CS}^{-}$trials in the MS group in comparisons of overall firing tendencies which did not take sequence effects into account (Fig. 3, Table 2).

The sequential dependencies of granule cell firing in the 2 lesion groups depicted in Figure 5 bear an interesting relation to the pattern exhibited by the control group, suggesting that perhaps granule cell discharges in intact animals are controlled by the combined effects of the active fiber projections that remained in each lesion group. Figure 6 shows that when both the MS and EC group sequential firing tendencies are summed together the sequentially dependent nature of granule cell firing

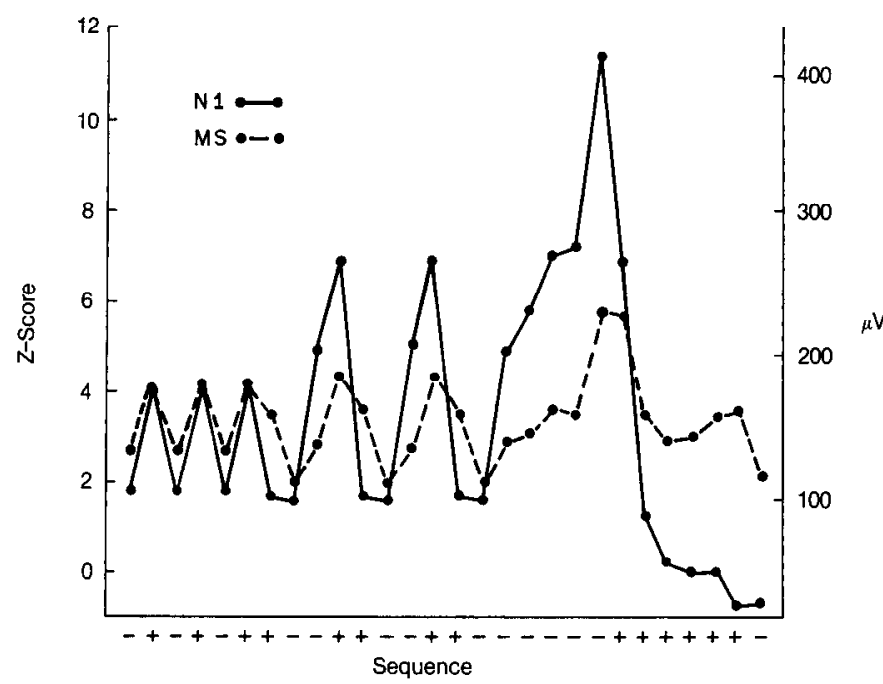

Figure 8. Sequence-dependent fluctuations in N1 component of evoked potential and granule cell discharge from MS lesion group. Similar fluctuations in granule cell ( $z$-score) discharge (dashed line) and N1 amplitude fluctuations (solid line) during the same trial series as shown in Figures 5 and 6 . Granule cell discharge pattern follows the sequential dependencies of the perforant path synaptic (N1) input in the absence of septal afferents.

markedly resembled the pattern exhibited by the control group. A parsimonious assumption regarding this observation is that the additive effects (i.e., convergence) of both the cortical (MS group) and subcortical (EC group) afferent inputs to the dentate granule cells are responsible for the sequential firing tendencies of these cells in normal animals.

\section{Relationship of granule cell sequentially dependent discharges to dentate gyrus sensory evoked potentials}

In prior experiments (see Deadwyler et al., 1981), the relationship between the granule cell discharge and the synaptic inputs from the EC and MS areas have been determined through recordings of identified and extensively characterized auditory croked potentials from the outer molecular layer of the dentate gyrus. The 2 identified negative-going components of this evoked potential, N1 and N2, are shown in Figure 7 in terms of their relationship to the discharge pattern of the dentate granule cells. The N1 component has been identified as reflecting the synaptic input via the perforant path, and the N2 component via connections with the septal region (Deadwyler et al., 1981, 1985). Since the granule cell discharges in each lesion group represent the functional aspects of the remaining synaptic influences, the trial-to-trial granule cell discharge pattern in each lesion group should resemble sequence-related amplitude fluctuations of the respective components of the tone-evoked potential. The amplitude fluctuations of the $\mathrm{N} 1$ and $\mathrm{N} 2$ components over the same trial sequences were therefore compared with the fluctuations in granule cell discharge tendencies from the lesion group with the appropriate extrinsic input pathway remaining intact.

Figure 8 shows the amplitude fluctuation in the N1 component for a representative normal animal compared with the granule cell discharges (mean $z$-score) in the MS (cortical input intact) group. The similarity of the MS group granule cell discharge pattern to the fluctuations in N1 amplitude across the 4 types of trial sequences is apparent. The dominant influences in both the $\mathrm{N} 1$ and granule cell fluctuations were double alter- 
nating sequences and runs of $\mathrm{CS}^{-}$and $\mathrm{CS}^{+}$trials. An important relationship between N1 amplitude and MS group g-cell discharges was the similar pattern of transition between sequence types (i.e., single to double alternation) coupled with the 1-trial phase shift with respect to the current trial (Fig. 8).

A similar correspondence was obtained between the N2 component of the averaged evoked potential in normal animals (Fig. 7) and the sequential pattern of granule cell discharges in the EC group as shown in Figure 9. The N2 component (recorded from the same animal as in Fig. 8) and the mean granule cell discharge of the EC group were closely linked and remained in phase with the current trial influence over most of the trial sequences. This pattern differed from the N1 amplitude fluctuation in normal animals and granule cell discharge in the MS group in 2 important ways: (1) the directional changes in both granule cell discharge and N2 amplitude were due to the current trial and were not phase shifted, and (2) the respective increases and decreases in granule cell discharge tendency tracked fluctuations in N2 amplitude in normal animals and were opposite $\mathrm{N} 1$ amplitude changes in normal animals and granule cell discharges in the MS group (compare $\mathrm{CS}^{+}$vs. $\mathrm{CS}^{-}$runs in Figs. 8, 9). Thus, elimination of afferent pathways in the septum or entorhinal cortex caused the granule cell discharge tendencies in both groups to follow closely the fluctuations of the remaining synaptic inputs, signified by similarity to the amplitude changes in the $\mathrm{N} 1$ and $\mathrm{N} 2$ components of the evoked potentials in normal animals.

\section{Discussion}

\section{Significance of cortical and subcortical inputs for tone-evoked granule cell discharge}

The results of this study show that hippocampal afferents originating in or coursing through the entorhinal and septal regions play significant roles in determining the discharge characteristics of the dentate granule cells to conditioned sensory stimuli. In addition, the pathways affected by these lesions appear to play a supportive role in auditory discrimination behavior in welltrained animals.

The most significant outcome of these investigations was the near abolishment of tone-evoked granule cell firing in the EC group. This suggests that transmission of sensory (auditory) information to the hippocampus is primarily via the cortical route through the perforant path, as predicted from early anatomic studies (Van Hoesen et al., 1972). Functional evidence for this is very compelling from the current results since animals with knife cut lesions and minimal damage to retrohippocampal structures (but severance of perforant path fibers) showed similar decrements in granule cell discharges to animals sustaining extensive hilateral destruction of all retrohippocampal structures (Figs. 1 and 4). Thus, disconnection of the EC from the dentate gyrus was sufficient to cause a critical suppression of tone-evoked granule cell discharges. Since septohippocampal and other dorsal projecting hippocampal afferents (see below) remained intact in EC animals, and since animals in the MS group retained moderate tone-evoked granule cell discharges (Fig. 3), an intact entorhinal-dentate gyrus connection would appear to be critical for sensory activation of dentate granule cells in most circumstances. The one exception to this conclusion was the significant increase in granule discharge observed in the EC group (Fig. 9) during a run of 5 consecutive $\mathrm{CS}^{+}$trials. Tone-evoked granule cell discharges were significantly modified but not abolished by septal lesions. The major effect of the lesion

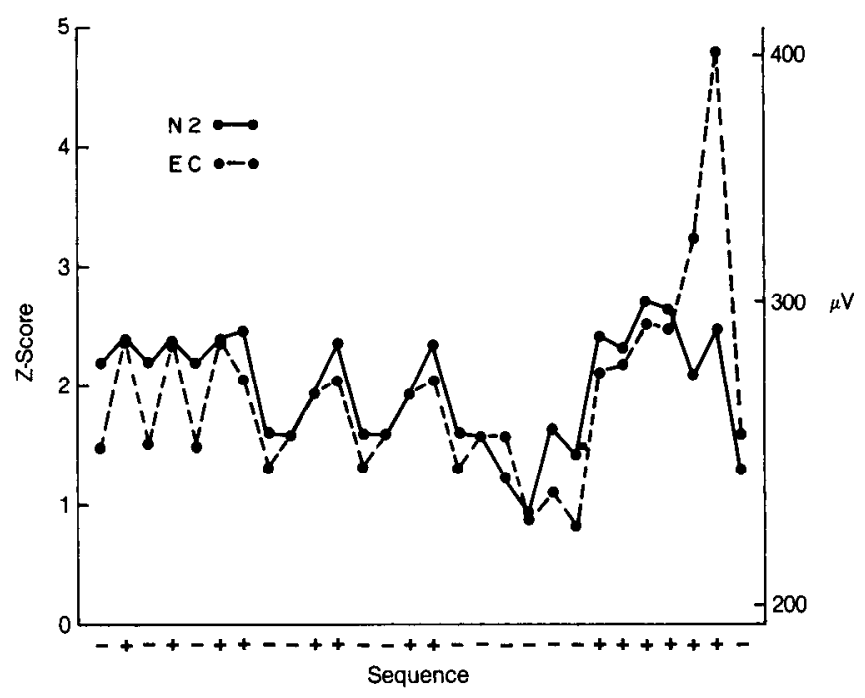

Figure 9. Relationship of the N2 component of the evoked potential to tone-evoked granule cell discharge ( $z$-scores) in the EC group (same as Fig. 8). Sequence-dependent fluctuations in the granule cell discharges (dashed line) are similar to amplitude fluctuations of the N2 component of the evoked potentials (solid line), indicating the pattern of control of granule cell discharges by septal afferents.

was the elimination of the sustained discharge to the $\mathrm{CS}^{+}$in the $200-400 \mathrm{msec}$. This finding is similar to that reported by Hirsh (1973) in which septal lesions produced a tendency for suspected granule cells to respond to the $\mathrm{CS}^{-}$and $\mathrm{CS}^{+}$with highly similar discharge patterns. In the present study, therc were also small but significant differences in the latency and magnitude of the initial (0-100 msec) granule cell discharges to the $\mathrm{CS}^{+}$and $\mathrm{CS}^{-}$ in the MS group in comparison with the control group (Fig. 3, Table 2), suggesting that the fibers entering the hippocampus via the septal region may control more subtle aspects of granule cell discharge than those interrupted by EC lesions.

It is likely that a nonhomogeneous population of hippocampal afferents was damaged or severed by both lesioning procedures. Although histochemical verification of deafferentiation of specific fiber systems was not used, those likely to be involved include the adrenergic (locus coeruleus), serotinergic (midbrain Raphe), and cholinergic (MS and diagonal band) neurotransmitter containing projection systems (see Swanson et al., 1987). Since these systems have dorsal and ventral fiber bundles projecting into the hippocampus, both the MS and EC lesions could have severed axons of these systems. However, the differential nature of the effects of the MS and EC lesions on granule cell activity indicates that either the dorsal and ventral projecting "limbs" of these systems have different physiological roles or some remaining systems may have dominated and masked the involvement of others. Since the aim of the lesion procedure was to deafferent the hippocampus via either the septal or entorhinal route, it is not possible to determine which of these 2 alternatives was responsible for the different effects of the lesions.

\section{Control of granule cell discharge by convergent inputs}

The differential effects of MS and EC lesions in controlling the topography of granule cell discharges to the $\mathrm{CS}^{+}$or $\mathrm{CS}^{-}$has important implications for the manner in which cortical and subcortical afferents modulate sensory activation of the granule 
cells. In normal animals, it appears that the cortical inputs do not provide enough of a differential signal in the $0-100 \mathrm{msec}$ interval to distinguish between $\mathrm{CS}^{+}$and $\mathrm{CS}^{-}$tone stimuli. This was shown in the MS group, where differentiated granule cell discharges to the $\mathrm{CS}^{+}$and the $\mathrm{CS}^{-}$tones only occurred in the subsequent 100-200 msec interval. Thus, the differential nature of the granule cell discharge in normal animals (see Foster et al., 1987) may require convergence from subcortical and cortical synaptic influences. This was suggested by the similarity of the sequentially dependent granule cell discharge patterns of the control group and the combined pattern produced by summing the 2 lesion group curves (Fig. 6). The fibers coursing through or originating within the septum were more influential if the animal experienced a run of $\mathrm{CS}^{+}$trials (EC group in Figs. 5 and 9), while the pathways entering via the EC were more dominant during a run of $\mathrm{CS}^{-}$trials (MS group in Figs. 5 and 8).

The influence of trial sequence on granule cell discharge in the MS group resembled in many respects the pattern exhibited by the N1 component of the sensory evoked potential. Past studies have shown that the amplitude fluctuations of this early component of the auditory evoked potential varies directly with amplitude fluctuations in the perforant path field potential recorded from the same location (Deadwyler, 1985). The N1 component is eliminated by EC lesions (Deadwyler et al., 1981), and most importantly for the current findings, N1 in normal animals increases in amplitude during runs of $\mathrm{CS}^{-}$trials and decreases during runs of $\mathrm{CS}^{+}$trials (West et al., 1982; Deadwyler et al., 1982, 1985). The correspondence between changes in the N1 component of the evoked potential and the sequential effects on granule cell firing tendencies recorded in animals with MS lesions makes it likely that the N1 component is functionally coupled to granule cell firing under these circumstances and reflects a dominant synaptic drive via perforant path axons.

A similar finding was observed in the sequentially dependent granule cell discharge patterns in the EC (septum intact) group and the dynamics of $\mathrm{N} 2$ component amplitude changes. In previous reports, we demonstrated that the $\mathrm{N} 2$ amplitude is controlled primarily by the reinforced status of the tone stimulus. During single-tone conditioning ( $\mathrm{CS}^{+}$trials only), $\mathrm{N} 2$ amplitude increased and stabilized at its maximum during acquisition and maintenance of the discrimination behavior but decreased rapidly in amplitude during bchavioral extinction (Deadwyler et al., 1981). N2 amplitude has been shown to decrease significantly during runs of negative trials and increase during runs of positive trials during 2-tone discrimination performance (West et al., 1982; Deadwyler et al., 1985). These amplitude fluctuations no longer occur after destruction of the medial septal nucleus (Deadwyler et al., 1981). The peak amplitude of the N2 potential is also coincident in time with the peak discharge of the granule cells $(70-100 \mathrm{msec})$ to the tone stimuli (Fig. 7). Several of the above features therefore suggest that N2 amplitude and increased granule cell discharges are directly coupled during runs of $\mathrm{CS}^{+}$trials in normal animals. Recently, it has been suggested that the septal input to the hippocampus disinhibits the granule cells by inhibiting (1) local circuit inhibitory interneurons or (2) cells in the hilus comprising the commissural/associational system (Berger et al., 1980; West et al., 1982; Abraham and Goddard, 1985). The N2 component may therefore indirectly control granule cell excitability through inhibitory interneurons (Bilkey and Goddard, 1985, 1987) representing a functional synaptic input from the septum to the granule cell layer and hilus, as indicated by our original description of this component (Deadwyler et al., 1981).
It is somewhat surprising that the MS and EC group curves could be combined directly to retrieve the sequential firing tendencies of the granule cells in normal animals. Postlesion axon sprouting has been shown to occur in the remaining intrinsic and extrinsic fiber systems of the hippocampus following lesions of the perforant path and MS in adult animals (Lynch et al., 1972; Cotman et al., 1973; Matthews et al., 1976; Lee et al., 1977; Nadler et al., 1977; Amaral et al., 1980; Stanfield and Cowan, 1982). The time course for recovery from surgery and training utilized in these investigations was adequate to reflcct sprouting of a number of these systems (West et al., 1975; Swanson et al., 1987). The degree to which such sprouting within the dentate gyrus influenced granule cell discharges could not be evaluated under the circumstances employed in this investigation; however, it is possible that the reduced magnitude of the combined MS and EC group granule cell discharge curve, compared with the control curve (Fig. 6), resulted from sproutinginduced changes in remaining intact fiber systems.

\section{Relationship of granule cell discharge to tone discrimination behavior}

It is important to note that the altered granule cell responsiveness in both the MS and EC groups occurred in the presence of maintained auditory discrimination behavior. Although associated with a 2 - to 3 -fold increase in error $\left(\mathrm{CS}^{-}\right)$responding, neither lesion altered $\mathrm{CS}^{+}$responding. Thereforc, since animals in both groups exhibited significant increases in intertrial responding, it is likely that the severed afferent pathways in both lesion groups were primarily involved in suppressing inappropriate responses. Selective neurotoxic destruction of the dentate granule cells also produces an increase in inappropriate behavioral responses in similar tasks (Toga and Lothman, 1983; Shull and Holloway, 1985). Thus, both the subcortical and cortical projections to the dentate gyrus appear to contribute significantly to the maintenance of optimum auditory discrimination performance in well-trained animals. However, the lack of a major influence on $\mathrm{CS}^{+}$trials indicates that other brain regions are more critical for this behavior. Several explanations of altered tone-evoked granule cell discharges which may have resulted from behavioral differences between control and lesioned animals, however, are ruled out by the lack of behavioral effects of the lesions. Since nose-poke latencies did not differ significantly among the groups, motor deficits can also be ruled out as responsible for granule cell firing differences. In addition, since both lesion groups exhibited clear evidence of maintained stimulus discrimination capacity, it is unlikely that tissue damage from the lesion produced major alterations in primary auditory pathways.

There were no significant changes in spontaneous (pretone) granule cell firing in either lesion group compared with control animals. This was somewhat surprising, especially since FC lesions nearly eliminated tone-evoked granule cell discharges. This finding suggests that some intrinsic mechanism was responsible for maintaining spontaneous granule cell activity in the absence of cortical inputs. Claiborne et al. (1986) have shown that collaterals of granule cell axons (mossy fibers) terminate on large mossy type neurons located within the hilus. It has been hypothesized that such neurons provide excitatory connections to the granule cell dendrites and cell bodies. These intrinsic connections would not have been disrupted by either lesion and therefore could have been responsible for the maintained spontaneous activity in the granule cell population in the absence of sensory inputs via the cortical pathways. Another alternative 
explanation is that the lesions may have had differential effects on granule cell responsiveness to the tone stimuli, with some granule cells showing increases as a result of the lesion, and others decreases, thus effecting no net change in the mean discharge pattern. However, since bilateral knife cuts produced a marked reduction in granule cell responsiveness in the same animal tested before and after the lesion (Figs. 3, 4), this explanation appears unlikely.

\section{Relationship of sensory evoked granule cell discharge to theta rhythm}

The septal nucleus has been shown by several investigators to influence granule cell firing via the theta rhythm (Bland, 1986). The significant reduction in peak latency and activation of granule cells in the MS group in the present study may have resulted from a change in theta triggered granule cell activity generated by the sensory stimulus (Bland et al., 1984). However, the relatively small influence of MS lesions on tone-evoked granule cell discharge in comparison with the marked effects on the theta rhythm reported by others (Buzsaki et al., 1983; Bland, 1986) and the fact that pretone granule cell activity was not changed in the MS group suggest that mechanisms responsible for theta synchronization had only a minor role (compared with EC lesions) in controlling sensory activation of granule cells in this study.

Differences in granule cell discharge rates in the control group on $\mathrm{CS}^{+}$versus $\mathrm{CS}^{-}$trials in the $200-400 \mathrm{msec}$ period could have resulted from increased theta rhythm from movements generated during the execution of the conditioned response (Buzsaki et al., 1983). However, since EC lesions produced a marked reduction in granule cell tone-evoked discharges with no change in behavioral response accuracy or latency, conditioned movements could not be entirely responsible for the prolonged granule cell discharge. We have previously shown that granule cells respond similarly in this task to theta cells recorded in other regions of the hippocampus (Christian and Deadwyler, 1986; Foster et al., 1987), suggesting that theta cells may be under the control of the same afferent pathways (cf. Deadwyler et al., 1987). Thus, similar changes in theta cells would be expected to be observed in animals with MS or EC lesions (Ranck, 1975; Fox and Ranck, 1981; Bland et al., 1983). Given this assumption, it is possible that the behavioral changes that accompanied the lesions in this study (increased error and intertrial responding) resulted from alterations in theta cell discharge patterns elsewhere in the hippocampus, as well as those observed in the granule cells of the dentate gyrus.

\section{Control of discriminative granule cell firing by convergent afferents}

The differential roles of the cortical and subcortical afferent inputs can be hypothesized from the information provided in this study. The subcortical inputs to the granule cells appcar to have a significant role in modifying discharges initiated by the cortical inputs. Granule cells, in the absence of subcortical inputs, did not discharge differentially to the $\mathrm{CS}^{+}$and $\mathrm{CS}^{-}$in the late $(200-400 \mathrm{msec})$ posttone period. The discharge pattern to the $\mathrm{CS}^{+}$was therefore not statistically different from that evoked by the $\mathrm{CS}^{-}$during the same posttone interval. For cortical lesions (EC group), the same behavioral deficit was associated with an absence of activation of the granule cells above pretone firing level at any time during the posttone period (Fig. 3 ). Thus, the behavioral deficits in both groups may have resulted from a failure to differentially activate the granule cells on $\mathrm{CS}^{+}$and $\mathrm{CS}^{-}$ trials, but for different reasons. Such a lack of differential granule cell activation in both lesion groups would be expected to be more influential during acquisition of the discrimination or during reversal of the discrimination (Berger and Orr, 1982; Deadwyler et al., 1982) than after substantial overtraining, as in the present study. However, the significant behavioral effects (increase of $250-300 \%$ responding to the $\mathrm{CS}^{-}$) observed in overtrained animals reflect the nontrivial impact of both types of lesion on auditory discrimination performance.

These results provide evidence for 3 important features of dentate granule cell operation. First, differential granule cell discharges evoked by conditioned sensory stimuli require intact connections with the cortex, in addition to the modulatory influences via convergent brain-stem and septal inputs. Second, elimination of either major extrinsic input pathway leads to an increase in error $\left(\mathrm{CS}^{-}\right)$and intertrial responding sufficient to influence well-trained sensory discrimination performance. The basis of the behavioral effect appears to be the elimination of differentiated granule cell discharges on $\mathrm{CS}^{+}$and $\mathrm{CS}^{-}$trials within a critical posttone interval (100-200 msec), a time at which behavioral responses are initiated (Christian and Deadwyler, 1986). Finally, the influence of prior trial sequences in biasing granule cell discharge tendencies in normal animals also appears to be controlled by trial-to-trial changes in the degree of sensory driving of the granule cells through convergent subcortical and cortical synaptic influences.

\section{References}

Abraham, W. C., and G. V. Goddard (1985) Multiple traces of neural activity in the hippocampus. In Memory Systems of the Brain, N. M. Weinberger, J. L. McGaugh, and G. Lynch, eds., pp. 62-76, Guilford, New York

Alvarez-Leefmans, F. J., and A. R. Gardner-Medwin (1975) Influences of the septum on the hippocampal dentate area which are unaccompanied by field potentials. J. Physiol. (Lond.) 249: 18 .

Amaral, D. G., C. Avandano, and W. M. Cotman (1980) The effects of neonatal 6-hydroxydopamine treatment on morphological plasticity in the dentate gyrus of the rat following entorhinal lesions. J. Comp. Neurol. 194: 171-191.

Beckstead, R. M. (1978) Afferent connections of the entorhinal area in the rat as demonstrated by retrograde cell-labeling with horseradish peroxidase. Brain Res. 152: 249-264.

Berger, T. W., and W. B. Orr (1982) Hippocampectomy selectively disrupts discriination reversal conditioning of the rabbit nictitating membrane response. Behav. Brain Res. 8: 48-68.

Berger, T. W., S. Semple-Rowland, and J. I. Basset (1980) Hippocampal polymorph neurons are the cells of origin for ipsilateral association and commissural afferents to the dentate gyrus. Brain Res. 215: 329-336.

Bilkey, D. K., and G. V. Goddard (1985) Medial septal facilitation of hippocampal granule cell activity is mediated by inhibition of inhibitory interneurones. Brain Res. 361: 99-106.

Bilkey, D. K., and G. V. Goddard (1987) Septo-hippocampal and commissural pathways antagonistically control inhibitory interneurons in the dentate gyrus. Brain Res. 405: 320-325.

Bland, B. H. (1986) The physiology and pharmacology of hippocampal formation theta rhythms. Prog. Neurobiol. 26: 1-54.

Bland, B. H., P. Andersen, T. Ganes, and O. Sveen (1980) Automated analysis of rhymicity of physiologically identified hippocampal formation neurons. Exp. Brain Res. 38: 205-219.

Bland, B. H., M. G. Seto, and C. J. Rowntree (1983) The relation of multiple hippocampal theta cell discharge rates to slow wave theta frequency. Physiol. Behav. 31: 111-117.

Bland, B. H., M. G. Seto, R. B. Sinclair, and S. M. Fraser (1984) The pharmacology of hippocampal theta cells: Evidence that the sensory processing correlate is cholinergic. Brain Res. 299: 121-131.

Bliss, T. V. P., and T. Lomo (1973) Long-lasting potentiation of synaptic transmission in the dentate area of the anesthetized rabbit following stimulation of the perforant path. J. Physiol. (Lond.) 232: 331356.

Buzsaki, G., L. S. Leung, and C. H. Vanderwolf (1983) Cellular bases 
of hippocampal EEG in the behaving rat. Brain Res. Rev. 6: 139171.

Campbell, K. A., T. C. Foster, R. E. Hampson, and S. A. Deadwyler (1986) Effects of delta-9-tetrahydrocannabinol on sensory-evoked discharges of granule cells in the dentate gyrus of behaving rats. $J$. Pharmacol. Exp. Therap. 239: 941-945.

Christian, E. P., and S. A. Deadwyler (1986) Behavioral functions and hippocampal cell types: Evidence for two nonoverlapping populations in the rat. J. Neurophysiol. 55: 331-348.

Claiborne, B. J., D. G. Amaral, and W. M. Cowan (1986) A light and electron microscopic analysis of the mossy fibers of the rat dentate gyrus. J. Comp. Neurol. 246: 435-458.

Cotman, C. W., D. A. Matthews, D. Taylor, and G. Lynch (1973) Synaptic rearrangement in the dentate gyrus: Histochemical evidence of adjustments after lesions in immature and adult rats. Proc. Natl. Acad. Sci. USA 70: 3473-3477.

Deadwyler, S. A. (1985) Involvement of hippocampus in learning and memory. In Memory Systems of the Brain, N. M. Weinberger, G. Lynch, and J. L. McGaugh, eds., pp. 134-149, Guilford, New York.

Deadwyler, S. A., J. R. West, C. W. Cotman, and G. S. Lynch (1975) A neurophysiological analysis of the commissural projections to dentate gyrus of the rat. J. Neurophysiol. 38: 167-184.

Deadwyler, S. A., J. Biela, G. Rose, M. O. West, and G. Lynch (1979a) An improved subminiature microdrive for recording from freely moving rats. Electroencephalogr. Clin. Neurophysiol. 47: 752-754.

Deadwyler, S. A., M. West, and G. Lynch (1979b) Activity of dentatc granule cells during learning: Differentiation of perforant path input. Brain Res. 169: 29-43.

Deadwyler, S. A., M. O. West, and J. H. Robinson (1981) Entorhinal and septal inputs differentially control sensory-evoked responses in the rat dentate gyrus. Science 211: 1181-1183.

Deadwyler, S. A., M. O. West, and E. P. Christian (1982) Neural activity in the dentate gyrus of the rat during the acquisition and performance of simple and complex discrimination learning. In Conditioning, C. Woody, ed., pp. 63-71, Plenum, New York.

Deadwyler, S. A., M. O. West, E. P. Christian, R. E. Hampson, and T. C. Foster (1985) Sequence-related changes in sensory-evoked potentials in the dentate gyrus: A mechanism for item-specific shortterm information storage in the hippocampus. Behav. Neurol. Biol. 44: 201-212.

Deadwyler, S. A., T. C. Foster, and R. E. Hampson (1987) Processing of sensory information in the hippocampus. Crit. Rev. Clin. Neurobiol. 2: 335-355.

Dudek, F. E., S. A. Deadwyler, C. W. Cotman, and G. Lynch (1976) Intracellular responses from granule cell layer in slices of rat hippocampus: Perforant path synapse. J. Neurophysiol. 39: 383-393.

Fantie, B. D., and G. V. Goddard (1983) Septal modulation of the population spike in the fascia dentata produced by perforant path stimulation in the rat. Brain Res. 252: 227-237.

Foster, T. C., E. P. Christian, R. E. Hampson, K. A. Campbell, and S. A. Deadwyler (1987) Sequential dependencies regulate sensory evoked responses of single units in the rat hippocampus. Brain Res. 408: 86-96.

Fox, S. E., and J. B. Ranck, Jr. (1979) Hippocampal field potentials evoked by stimulation of multiple limbic structures in freely moving rats. Neuroscience $4: 1467-1478$.

Fox, S. E., and J. B. Ranck, Jr. (1981) Electrophysiological characteristics of hippocampal complex-spike cells and theta cells. Exp. Brain Res. 41: 399-410.

Fricke, R. A., and D. A. Prince (1984) Electrophysiology of dentate gyrus cells. J. Neurophysiol. 51: 195-209.

Gold, R. M., G. Kapatos, and R. J. Carey (1973) A retracting wire knife for stereotaxic brain surgery made from a microliter syringe. Physiol. Behav. 10: 813-815.

Hirsh, R. (1973) The effect of septal input upon hippocampal unit response in normal conditions in rats. Brain Res. 58: 234-239.

Hjorth-Simonsen, A., and B. Jeune (1972) Origin and termination of the hippocampal perforant path in the rat studied by silver impregnation. J. Comp. Neurol. 144: 215-252.

Lee, K., E. J. Stanford, C. W. Cotman, and G. S. Lynch (1977) Ul- trastructural evidence for bouton proliferation in the partially deafferented dentate gyrus in the rat. Exp. Brain Res. 29: 475-485.

Lømo, T. (1971) Patterns of activation in a monosynaptic cortical pathway: The perforant path input to the dentate area of the hippocampal formation. Exp. Brain. Res. 12: 18-45.

Lynch, G., D. A. Matthews, S. Mosko, T. Parks, and C. W. Cotman (1972) Induced acetylcholinesterase-rich layer in rat dentate gyrus following entorhinal lesions. Brain Res. 42: 311-318.

Lynch, G., G. Rose, and G. Gall (1977) Anatomical and functional aspects of the septo-hippocampal projections. In Functions of the Septo-Hippocampal System [Ciba Found. Symp., Vol. 59 (New Series)], p. 5, Elsevier, New York.

Matthews, D. A., C. Cotman, and G. Lynch (1976) An electron microscopic study of lesion-induced synaptogenesis in the dentate gyrus of the adult rat. I. Magnitude and time course of degeneration. Brain Res. 115: 1-21.

McNaughton, N., and J. J. Miller (1984) Medial septal projections to the dentate gyrus of the rat: Electrophysiological analysis of distribution and plasticity. Exp. Brain Res. 56: 243-256.

Miller, S. W., and P. M. Groves (1977) Sensory evoked neural activity in the hippocampus before and after lesions of the medial septal nuclei. Physiol. Behav. 18: 141.

Mosko, S., G. Lynch, and C. W. Cotman (1973) The distribution of septal projections to the hippocampus of the rat. J. Comp. Neurol. 152: $163-174$.

Nadler, J. V., C. W. Cotman, and G. S. Lynch (1977) Histochemical evidence of altered development of cholinergic fibers in the rat dentate gyrus following lesions. I. Time course after complete unilateral entorhinal lesion at various ages. J. Comp. Neurol. 171: 561-588.

Raisman, G. (1966) The connections of the septum. Brain 89: 317348.

Ranck, J. B., Jr. (1975) Behavioral correlates and firing repertoires of neurones in the dorsal hippocampal formation. In The Hippocampus, R. L. Isaacson and K. H. Pribram, eds., pp. 204-244, Plenum, New York.

Rose, A. M., T. Hattori, and H. C. Fibiger (1976) Analysis of the septohippocampal pathway by light and electron microscopic autoradiography. Brain Res. 180: 170-174.

Segal, M., and S. Landis (1974) Afferents to the hippocampus of the rat studied with the method of retrograde transport of horseradish peroxidase. Brain Res. 78: 1-15.

Shull, R. N., and F. A. Holloway (1985) Behavioral effects of hippocampal system lesions on rats in an operant paradigm. Brain Res. Bull. 14: 315-322.

Stanfield, B., and W. M. Cowan (1982) The sprouting of septal afferents to the dentate gyrus after lesions of the entorhinal cortex in adult rats. Brain Res. 232: 162-170.

Steward, O. (1976) Topographic organization of the projections from the entorhinal area to the hippocampal formation of the rat. J. Comp. Neurol. 167: 285-314.

Swanson, L. W., C. Kohler, and A. Bjorklund (1987) The limbic region. I: The septohippocampal system. In Handbook of Chemical Neuroanatomy, A. Bjorklund, T. Hökfelt, and L. W. Swanson, eds., pp. 125-255, Elsevier, Amsterdam.

Toga, A. W., and E. W. Lothman (1983) Learning deficits after lesions of dentate gyrus granule cells. Exp. Neurol. 82: 192-202.

Van Hoesen, G. W., D. N. Pandya, and N. Butters (1972) Cortical afferents to the entorhinal cortex of the rhesus monkey. Science 175 : 1471-1473.

West, J. R., S. A. Deadwyler, C. W. Cotman, and G. S. Lynch (1975) Time-dependent changes in commissural field potentials in the dentate gyrus following lesions of the entorhinal cortex in adult rats: A neurophysiological analysis of axon sprouting. Brain Res. 97: 215233.

West, M. O., E. P. Christian, J. H. Robinson, and S. A. Deadwyler (1982) Evoked potentials in the dentate gyrus reflect the retention of past sensory events. Neurosci. Lett. 28: 319-324.

Wilson, R. C., and O. Stcward (1978) Polysynaptic activation of the dentate gyrus of the hippocampal formation: An olfactory input via the lateral entorhinal cortex. Exp. Brian Res. 33: 523-534. 